\title{
A Haven During Migration
}

Hugh McLaughlin, Lewvan.

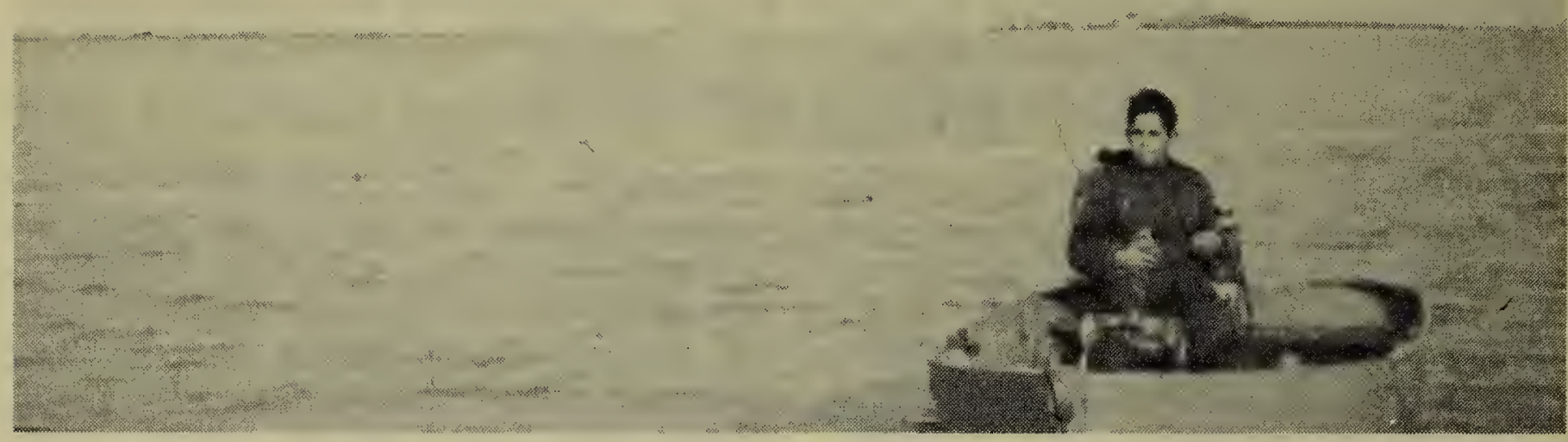

The McLaughlin Farm in Springtime.

$\mathbf{N}$ EARLY every spring the melting snow floods a considerable portion of nearby land and for a few days the new found lake becomes host to a babbling, garrulous convention of migrating water fowl. It is a sort of refueling station where the expanse of water and the convenient feed, to be gleaned from last year's stubble, make a resting place before the flight continues. The mild length of field can be travelled by a boat. In spots the stubble peeks through the water, but in other places three to four feet of water makes for free travelling. A high spot makes a convenient island which when undisturbed is covered with ducks, like flies. In lesser numbers their more reserved and wary relatives, the geese, mingle with the throng. And in stately elegance, with heads high, the swans add their distinctive presence. They have been counted at approximately two hundred at a time.

This expanse of water and volume of birds give an unfamiliar air to a stubble field. But there's the spot, I imagine, where the elevator on the combine broke down last fall, and there-where the oar plunges deep beneath the surface, that's where we struggled with jack and plank to release the combine from last fall's unseasonable mud, to continue with the harvest.

Such thoughts are foreign to the moment. We are playing host to this vast flock and they are welcome to the gleanings from the ground stubble, and the restful water is theirs to enjoy. The limpid spring air carries myriad voices far-the flat prairie is alive with this fore- runner of summer. I rejoice in the miracle of their sure returning. We see only half their lives here. In what far off climes they've wintered I know not. But to nest and raise their young to a new generation, they travel this journey and we are glad at the sight. A group of Sandhill Cranes come floating in to join their resonant voices with the rest.

Soon this high tide forces open snow-choked ditches and in a matter of days the water goes on down stream into the Souris Creek. Fields dry up and soon the new crop is being sown. The usual number, eight or ten ducks, remain to rest. Off in the not too far distance a dozen Sandhill Cranes linger for a few days - striding around like sedate couples in their grey dress clothes-and then suddenly breaking out in a series of wing-flapping and jumping. It is their courtship dance. If the tractor comes too close, there is a leisurely run, a take-off and flight to the other side of the field.

There is some fertilizing value left by these birds, and with the flood the crop is away to a good start. Still all the harvest of the season is not wheat alone. This thrill of spring is a highlight of the returns, for back of all this great distance travelled and route plotted, must be a greater impulse than bird brains. In awe I faintly recall some verse almost forgotten:

"He who from zone to zone

Guides through the boundless sky thy certain flight,

In the long hours that I must tread alone

Will lead my steps aright." 